\title{
RED WINE POLYPHENOLS REVERSE DEPRESSIVE-LIKE BEHAVIORS IN MICE INDUCED BY REPEATED CORTICOSTERONE TREATMENT
}

\section{POLIFENÓIS DO VINHO TINTO REVERTEM COMPORTAMENTOS DEPRESSIVOS EM RATOS INDUZIDOS PELO TRATAMENTO REPETIDO COM CORTICOSTERONA}

\author{
Tingxu Yan ${ }^{1}$, Yingying Sun ${ }^{2}$, Bo Wu ${ }^{1}$, Feng $\mathrm{Xiao}^{2}$, Kaishun $\mathrm{Bi}^{3}$, Baoshan $\mathrm{Sun}^{1,4}$, Ying Jia ${ }^{{ }^{*}}$ \\ ${ }^{1}$ School of Functional Food and Wine, Shenyang Pharmaceutical University, Wenhua Road 103, Shenyang 110016, PR China. \\ ${ }^{2}$ School of Traditional Chinese Materia Medica, Shenyang Pharmaceutical University, Wenhua Road 103, Shenyang, PR China. \\ ${ }^{3}$ School of Pharmacy, Shenyang Pharmaceutical University, Wenhua Road 103, Shenyang 110016, PR China. \\ ${ }^{4}$ Instituto Nacional de Investigação Agrária e Veterinária, INIAV-Dois Portos, Quinta da Almoinha, 2565-191 Dois Portos, Portugal. \\ * Corresponding author: Tel: +86-24-43520305, e-mail: jiayingsyphu@126.com
}

(Received 04.04.2019. Accepted 02.12.2019)

\section{SUMMARY}

The aim of this study was to investigate the antidepressant-like effect of red wine phenolic extracts in mouse model exposed to exogenous corticosterone. The results showed that 3 -week corticosterone injections caused depression-like behavior in mice, as indicated by the significant decrease in sucrose consumption and increase immobility time in the forced swimming test (FST). Red wine phenolic extracts treatment significantly reduced serum corticosterone levels. Moreover, it was found that red wine phenolic extract increased the brain-derived neurotrophic factor protein (BNDF) and tropomyosin-related kinase B (TrkB) phosphorylation and cAMP-responsive element binding protein (CREB) phosphorylation levels in the hippocampus and prefrontal cortex. However, K252a, an inhibitor of TrkB, completely abolished those antidepressant-like effects. These results suggested that the red wine phenolic extracts produce an antidepressant-like effect in corticosteronetreated mice, at least in part, which is possibly mediated by modulating hypothalamic-pituitary-adrenal (HPA) axis, BDNF, TrkB and CREB phosphorylation levels in the brain region of mice.

\section{RESUMO}

O objetivo deste trabalho foi estudar o efeito antidepressivo de extratos fenólicos do vinho tinto em rato-modelo exposto à corticosterona exógena. Os resultados mostraram que injeções de corticosterona de 3 semanas causaram comportamento semelhante à depressão em ratos, como indicado pela diminuição significativa no consumo de sacarose e aumento do tempo de imobilidade em teste de natação forçada (FST). O tratamento com extratos fenólicos de vinho tinto reduziu significativamente os níveis séricos de corticosterona. Além disso, verificou-se que o extrato fenólico do vinho tinto aumentou a proteína do fator neurotrófico derivado do cérebro (BNDF) e fosforilação da quinase $\mathrm{B}$ associada à tropomiosina (TrkB) e os níveis de fosforilação da proteína de ligação ao elemento cAMP-responsivo (CREB) no hipocampo e no córtex pré-frontal. No entanto, K252a, um inibidor de TrkB, aboliu completamente os efeitos do tipo antidepressivo. Estes resultados sugerem que os extratos fenólicos do vinho tinto produzem um efeito antidepressivo em ratos tratados com corticosterona, pelo menos em parte, o que é possivelmente mediado pela modulação do eixo hipotálamo-hipófise-adrenal (HPA), BDNF, TrkB e níveis de fosforilação de CREB na região do cérebro dos ratos.

Key words: depressive behavior, polyphenols, red wine.

Palavras-chave: comportamento depressivo, polifenóis, vinho tinto.

\section{INTRODUCTION}

Major depression disorder (MDD) is one of the most common debilitating mood disorders worldwide and becoming the second leading disease contributing to the years lived with disability by 2013 (Dean and Keshavan, 2017). The prominent and persistent low mood, mental retardation, cognitive impairment, volitional decline and somatic symptoms companied the patients' lifelong and impaired their social

115

This is an Open Access article distributed under the terms of the Creative Commons Attribution License (http://creativecommons.org/licenses/by/4.0), which permits unrestricted use, distribution, and reproduction in any medium, provided the original work is properly cited. 
functions. The lifetime and 12-month prevalence estimates for MDD were 5.8\% and 2.2\% in an Asian multi-racial population, respectively (Chong et al., 2012). On the other hand, diabetes, cardiometabolic disease, obesity and other comorbidity associated with MDD (Badescu et al., 2016; Jani et al., 2017), emerge as a serious health concern.

Despite its higher prevalence, the mechanisms associated with the pathogenesis of MDD have yet to be completely understood and current treatments remain ineffective in a large subset of patients (LimaOjeda et al., 2018). A growing literature has shown that the hypothalamic-pituitary-adrenal (HPA) axis plays a major role in the regulation of a variety of physiological disorders, such as depression (Menke, 2019). In this classic neuroendocrine circuit, limbic and hypothalamic brain structures coordinate emotional, cognitive, neuroendocrine and autonomic inputs, which together determine the magnitude and specificity of an individual's behavioral, neural and hormonal responses to stress. This response is mediated by glucocorticoid hormones (corticosterone in rodents and cortisol in humans) (Gerritsen et al., 2017). Increased level of corticosterone has mostly been ascribed to impaired feedback regulation of the HPA axis, possibly caused by altered function of the glucocorticoid receptor and induced depressive disorder (Leistner and Menke, 2018).

Moreover, brain-derived neurotrophic factor (BDNF) and its receptor, tropomyosin receptor kinase $\mathrm{B}$ (TrkB) downstream signaling are integral to a range of neural functions, including synaptic plasticity and exhibits activity-dependent regulation of expression. The neurotrophic model of depression hypothesizes that the level of BDNF is decreased during the depression, which has been certified by the concentration of BDNF detected in the serum and hippocampus of postmortem in several publications (Buttenschon et al., 2015; Reinhart et al., 2015). Additionally, cAMP-response element binding protein (CREB) signaling also can increase the transcription of BDNF in the soma or transportation to dendrites (Wang et al., 2017), contribute to the actions of antidepressant treatments.

A depression animal model by repeated corticosterone treatment has been performed widely in mice, which resulted in depressive-like behavior marked by significant changes in behavioral traits, neurochemistry and brain (Ding et al., 2018). Corticosterone-induced depression model has advantages over the stress models (such as restraint stress exposure) that avoid the possibility of potential habituation effects and variation in HPA axis response to stress stimuli (Obasi et al., 2019).
Previous reports have shown that exogenous corticosterone administration develops depressionlike behavior in mice during forced swim test, sucrose consumption test and tail suspension test (Fenton et al., 2015; Zhang et al., 2015). Therefore, these findings suggest that a chronic corticosterone treatment appears to model depression-like state in mice is suitable for evaluating the efficacy of potential antidepressant candidates and to explore the mechanism of action of antidepressants.

Recent studies have shown that plant polyphenols possess a number of beneficial properties, such as reducing the risks of cancer and heart diseases (Mattera et al., 2017; Amor et al., 2018); green tea and grape powder have shown effect on alleviating cognitive impairments and leading to a lower prevalence of depressive symptoms (Mulero et al., 2015; Patki et al., 2015; Solank et al., 2015). It has been recognized that red wines are one of the richest sources of polyphenols and thus possess beneficial effects on human health when drunk in moderation (Nash et al., 2018). However, it is unknown whether red wine has a potential effect on alleviating depressive disorder, and the impact of polyphenols content of antidepressant-like effect. Therefore, the objective of this study was to verify the antidepressant-like effects of red wine phenolic extracts in a mouse model of depression induced by repeated injections of corticosterone, and to further investigate the relationship between BDNF signaling and the antidepressant-like effect of red wine phenolic extracts.

\section{MATERIAL AND METHODS}

\section{Red wine phenolic extracts}

The two different red wine phenolic extracts tested, one from red wine at 2 days of maceration (TPXMT2) and another from red wine at 7 days of maceration (TPx-MT7), were obtained as described in the previous work (Sun et al., 2011). Briefly, red wine was made by classic vinification method with Vitis vinifera varieties (Castelão:Tinta Miuda; 3:2; $\mathrm{w} / \mathrm{w}$ ) harvested at maturity. After 7 days of maceration when alcoholic fermentation was finished, the mash was pressed. About $80 \mathrm{~mL}$ of the wine samples was evaporated under vacuum at less than 30 ${ }^{\circ} \mathrm{C}$ to remove ethanol and then loaded onto an open column $(200 \mathrm{~mm} \times 25 \mathrm{~mm}$ i.d. $)$ packed with LiChroprep RP-18 (25-40 $\mu \mathrm{m}$ particle size) already preconditioned with distilled water. The column was washed with $200 \mathrm{~mL}$ of distilled water, followed by $150 \mathrm{~mL}$ of methanol to recover TPs. The methanol fraction was added with an equal volume of distilled 
water, evaporated under vacuum at less than $30^{\circ} \mathrm{C}$ to remove methanol, and then lyophilized to obtain TPs extract (TPx). The obtained polyphenol extracts from the wine at 2 and 7 days of maceration named TPxMT2 and TPX-MT7, respectively. Both red wine phenolic extracts present high purity in polyphenols ( $>91 \%$; w/w) but TPx-MT2 contains more anthocyanins than TPx-MT7 $(14.00 \%$ w/w versus $8.43 \% \quad \mathrm{w} / \mathrm{w})$ while TPX-MT7 contains more proanthocyanidins than TPX-MT2 $(6.17 \% \mathrm{w} / \mathrm{w}$ versus $4.61 \% \mathrm{w} / \mathrm{w}$ ) (Sun et al., 2011).

\section{Animals}

Adult male Kunming mice (weighing $20 \pm 2$ g) were purchased from the Experimental Animal Center of Shenyang Pharmaceutical University (Shenyang, China). All of them were maintained under standard laboratory conditions of constant temperature $(23 \pm 1$ $\left.{ }^{\circ} \mathrm{C}\right)$, relative humidity $(50 \pm 10 \%)$ and a $12 \mathrm{~h}$ light/dark cycle (light from 7:00 a.m. to 7:00 p.m.) with food and water available ad libitum and were allowed to habituate to the novel environment for one week prior to use in experiment. The experiment was carried out in compliance with the National Institutes of Health and institutional guidelines for the humane care of animals and was approved by the Animal Care Committee of Shenyang Pharmaceutical University. Every effort was made to minimize the number of animals used and any pain and discomfort experienced by the subjects.

\section{Drug administration and experimental groups}

The mice were randomly assigned eleven groups ( $\mathrm{n}=8$ /group): control group, vehicle group, corticosterone groups: corticosterone only, TPx-MT2 $(10 \mathrm{mg} / \mathrm{kg})$, TPx-MT2 (10 mg/kg) + K252a, TPxMT2 (20 mg/kg), TPx-MT2 (20 mg/kg) + K252a, TPx-MT7 (10 mg/kg), TPx-MT7 (10 mg/kg) + K252a, TPx-MT7 (20 mg/kg), TPx-MT7 (20 mg/kg) $+\mathrm{K} 252 \mathrm{a}$. Corticosterone (TCI, Japan) was dissolved in. Corticosterone was injected subcutaneously at 40 $\mathrm{mg} / \mathrm{kg}$ in a volume of $1 \mathrm{~mL} / \mathrm{kg}$ as this dose reliably increases depression-like behavior in mice without altering nonspecific motor activity (Fenton et al., 2015). Control mice received the same volume of normal saline. Mice in the vehicle group received only vehicle without corticosterone for the same period. TPx-MT2 and TPx-MT7, Castelão and Tinta Miuda red wine extract (INIAV Dois Portos, Portugal) were dissolved in purified water and administered by gavage $30 \mathrm{~min}$ prior to the corticosterone injection. The repeated drug treatment was performed once daily and continuously for 21 days. K252a (Santa Cruz, USA), an inhibitor of BDNF receptor TrkB, was dissolved in $0.1 \%$ DMSO in saline and injected i.p. in a volume of $10 \mathrm{~mL} / \mathrm{kg}$ before $30 \mathrm{~min}$ of gavage administration (Luo et al., 2015). The dose of TPx-MT was chosen based on the results of preliminary experiment. The behavioral tests were carried out $24 \mathrm{~h}$ after the last injection. One animal from each group was tested in sequence.

\section{Sucrose preference test}

Sucrose preference test was carried out $24 \mathrm{~h}$ after the last injection as described previously (Chiba et al., 2012). Briefly, prior to testing, mice were trained to adapt to the sucrose solution $(1 \%, \mathrm{w} / \mathrm{v})$ : two bottles of sucrose solution were placed in each cage for $24 \mathrm{~h}$, and then one bottle of sucrose solution was replaced with water for $24 \mathrm{~h}$. After adaptation, mice were deprived of water and food for $24 \mathrm{~h}$. Sucrose preference test was conducted with mice housed in the individual cage and free access to the two bottles, one containing $100 \mathrm{~mL}$ of sucrose solution $(1 \% \mathrm{w} / \mathrm{v})$ and the other $100 \mathrm{~mL}$ of water. After $1 \mathrm{~h}$, the volumes of consumed sucrose solution and water were recorded and the sucrose preference was calculated as the sucrose preference (\%) = sucrose consumption/(sucrose consumption + water consumption) $\times 100 \%$.

\section{Forced swimming test}

The forced swimming test (FST) was carried out on mice, according to the method of Kruk-Slomka et al. (2015). Briefly, the individual mouse was subjected to swimming stress session for $15 \mathrm{~min}$ (pre-test), in a vertical glass cylinder $(25 \mathrm{~cm}$ high, $14 \mathrm{~cm}$ in diameter) containing $10 \mathrm{~cm}$ of water, maintained at $25 \pm 2{ }^{\circ} \mathrm{C}$. After $24 \mathrm{~h}$, FST was carried out and the total duration of immobility (seconds) was recorded during the last 4 min of a single 6 min test session. A mouse was judged to be immobile when it ceased struggling and remained floating motionless in the water, making only small movements necessary to keep its head above water. The water in the container was changed after each trial.

\section{Serum corticosterone measurement}

After the behavioral test, mice were euthanized by decapitation and blood was collected ( $\mathrm{Yu}$ et al., 2015). Serum corticosterone level was measured using a commercially customized ELISA kit (Liyu Bioengineering Ltd., Shanghai, China) according to the manufacturer's protocol. Briefly, $50 \mu \mathrm{L}$ of sample and standard solutions were added to the already precoated antibody plate provided with the kit and incubated for $30 \mathrm{~min}$ at $37{ }^{\circ} \mathrm{C}$. The reaction was ended and followed by washing, $50 \mu \mathrm{L}$ of the TMB color reagent was added and incubated for $20 \mathrm{~min}$ without shaking. The reaction was stopped by adding $50 \mu \mathrm{L}$ of stop solution and absorbance was read at 
$450 \mathrm{~nm}$ using a microplate reader (Varioskan flash, Thermoscientific, USA).

\section{Tissue collection and biochemical analysis}

Whole brains were rapidly removed from the mice and chilled in an ice-cold saline solution after blood collection. Brain regions of the hippocampus and prefrontal cortex were dissected on a cold plate and immediately frozen in liquid nitrogen. The tissue samples were stored at $-80{ }^{\circ} \mathrm{C}$ until assay.

The level of BDNF, pCREB, CREB, pTrkB and TrkB were measured using commercially available enzyme-linked immunosorbent assay ELISA kits (Liyu Bioengineering Ltd., Shanghai, China) according to the manufacturer's instructions. Absorbance was measured at $450 \mathrm{~nm}$ using a microplate reader (Varioskan flash, Thermoscientific, USA).

\section{Statistical analysis}

All data were analyzed using a one-way analysis of variance (ANOVA) with repeated measures, followed by Tukey HSD post-hoc test when significant main effects were indicated. All analyses were two-tailed and $* \mathrm{p}<0.05$ was considered significant $a$ priori.

\section{RESULTS AND DISCUSSION}

\section{Sucrose consumption}

As shown in Figure 1, a 3-week corticosterone exposure significantly reduced the percentage of sucrose consumption in the stressed mice in comparison with the control animals $[\mathrm{F}(10,77)=$ $9.616, \mathrm{p}<0.01]$. However, post-hoc analysis revealed that long-term treatment of corticosterone mice with TPx-MT7 (10, $20 \mathrm{mg} / \mathrm{kg})$ increased sucrose preference, as compared to corticosterone-exposed mice (respectively, $\mathrm{p}<0.05 ; \mathrm{p}<0.01$ ). But with TPxMT2 treatment, there are no similar results obtained. Chronic treatment with TPx-MT2 or TPx-MT7 showed no effects on sucrose preference of K252ainjected animals. The sucrose preference test is an indicator of anhedonia-like behavioral change. Anhedonia a core symptom of major depression among humans is modeled by inducing a decrease in responsiveness to rewards, as reflected by the reduced consumption of and/or preference for sweetened solutions (Rzepa and McCabe, 2019). In the present study, the data are in line with previous findings showing that a significant decrease in the percentage of sucrose consumption of mice (Cerniauskas et al., 2019). Red wine extract significantly reversed this behavioral change, which suggested the antidepressant-like function.

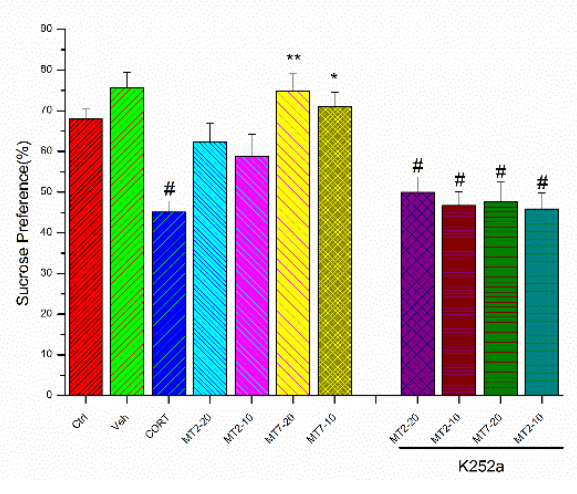

Figure 1. Effect of TPx-MT2 and TPx-MT7 on sucrose consumption. All the values are given as mean \pm standard error of mean (SEM) $(\mathrm{n}=8),{ }^{*} p<0.05,{ }^{* *} p<0.01$ vs CORT; ${ }^{*} p<0.05$ vs control.

Efeito do TPx-MT2 e TPx-MT7 no consumo de sacarose. Todos os valores são dados como média $\pm \operatorname{SEM}(n=8),{ }^{*} p<0,05, * * p<0,01$ vs CORT; ${ }^{*} p<0,05$ vs controlo.

\section{Immobility time in the FST}

The effects of treatment with TPx-MT2 and TPXMT7 on the immobility time were presented in Figure 2. TPx-MT2 (20 mg/kg) and TPx-MT7 (10, 20 $\mathrm{mg} / \mathrm{kg}$ ) treatment significantly increased the immobility time of stressed animals compare to the corticosterone-treated only group $[\mathrm{F}(10,77)=20.077$, $\mathrm{p}<0.01]$.

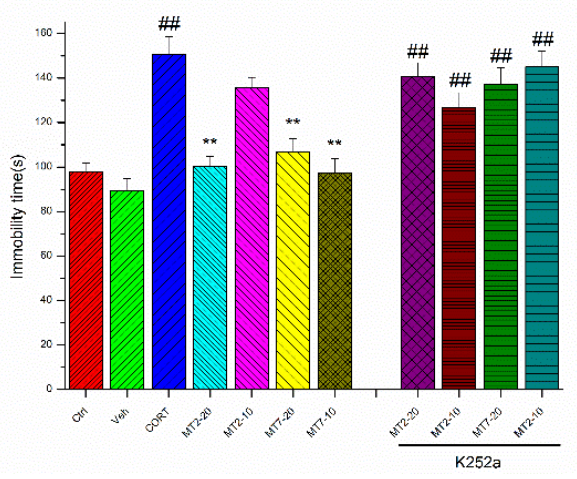

Figure 2. Effect of TPx-MT2 and TPx-MT7 on the immobility time in forced swimming test. All the values are given as mean \pm SEM $(\mathrm{n}=8),{ }^{* *} p<0.01$ v CORT, ${ }^{\#} p<0.01$ vs control.

Efeito de TPx-MT2 e TPx-MT7 no tempo de imobilidade em teste de natação forçada. Todos os valores são dados como média \pm $\operatorname{SEM}(n=8),{ }^{* *} p<0,01$ vs CORT, ${ }^{\#} p<0,01$ vs controlo.

On the contrary, there were no significant differences of the immobility time between K252a-treated groups 
and corticosterone -treated group also including TPxMT2 $(10 \mathrm{mg} / \mathrm{kg})$ group. FST is a behavioral despair test useful for probing the pathological mechanism of depression and for the evaluation of antidepressant drugs (Zhang et al., 2019a). This neurobehavioral alteration was also ameliorated by red wine extract, thereby underlining the effectiveness of red wine as an antidepressant candidate.

\section{Serum corticosterone levels}

As shown in Figure 3, there was a significant effect of corticosterone exposure on serum corticosterone concentrations $[\mathrm{F}(10,77)=10.092, \mathrm{p}<0.05]$. The corticosterone-induced increases in serum corticosterone levels were significantly reduced in mice treated with TPx-MT2 $(20 \mathrm{mg} / \mathrm{kg})(\mathrm{p}<0.05)$ and TPx-MT7 (10, $20 \mathrm{mg} / \mathrm{kg})(\mathrm{p}<0.05)$. However, these reductions were robust by K252a injection. Chronic treatment with TPx-MT2 $(10 \mathrm{mg} / \mathrm{kg})$ showed no effect on the serum corticosterone level of corticosterone-treated animals. This means that exogenous corticosterone results in an absolute increase in circulating serum corticosterone levels, an indicator of stress and depression in mice. Thus, the present study revealed that the behavioral consequences of repeated corticosterone administration were accompanied by dysregulation of the HPA axis.

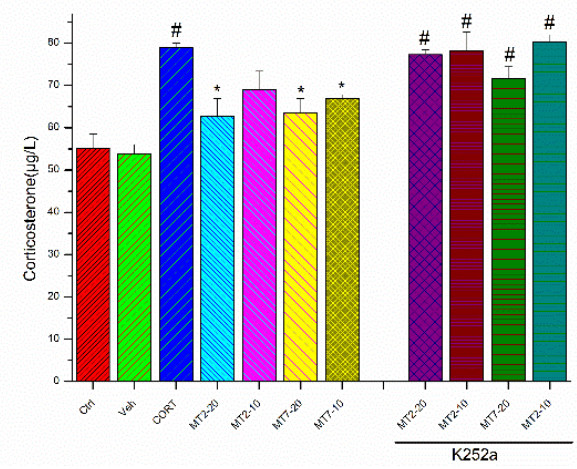

Figure 3. Effect of TPx-MT2 and TPx-MT7 on serum corticosterone concentration. All the values are given as mean \pm $\operatorname{SEM}(\mathrm{n}=8),{ }^{*} p<0.05$ vs CORT; ${ }^{*} p<0.05$ vs control.

Efeito do TPx-MT2 e TPx-MT7 na concentração sérica de corticosterona. Todos os valores são dados como média \pm EPM (n $=8),{ }^{*} p<0,05$ vs CORT; ${ }^{*} p<0,05$ vs controlo.

\section{BDNF levels}

As shown in Figure 4, exposure to corticosterone significantly decreased both hippocampal $[F(10,77)=11.382, p<0.01]$ (Figure 4A) and prefrontal cortex BDNF levels $[\mathrm{F}(10,77)=8.092, \mathrm{p}<0.05]$ (Figure 4B) as compared to the control animals. Treatment with a daily dose of TPx-MT2 $(20 \mathrm{mg} / \mathrm{kg})$ and TPxMT7 $(20 \mathrm{mg} / \mathrm{kg})$ significantly attenuated the decrease in BDNF protein level $(\mathrm{p}<0.05$ and $\mathrm{p}<0.05$, respectively) in the hippocampus as compared to the only corticosterone-treated mice. And this attenuated effect in the hippocampus was blocked by K252a. But the BDNF levels in the prefrontal cortex of both TPxMT2 and TPX-MT7 treatment groups have no alterations compare to the corticosterone-treated group.
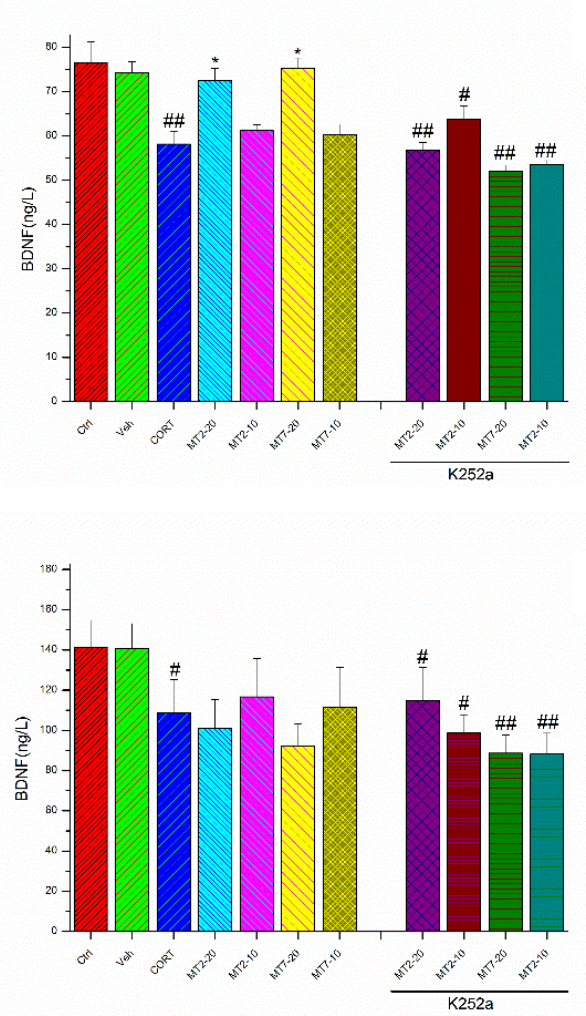

B

Figure 4. Effect of TPx-MT2 and TPx-MT7 on BDNF level of hippocampus (A) and prefrontal cortex (B). All the values are given as mean $\pm \operatorname{SEM}(\mathrm{n}=8),{ }^{*} p<0.05$ vs CORT; ${ }^{*} p<0.05,{ }^{\#} p<0.01$ vs control.

Efeito de TPx-MT2 e TPx-MT7 no nivel de BDNF do hipocampo (A) e do córtex pré-frontal (B). Todos os valores são dados como média \pm SEM $(n=8),{ }^{*} p<0.05$ vs CORT; ${ }^{p}<<0.05,{ }^{\# \#} p<0.01$ vs controlo.

The role of BDNF in the pathogenesis of depression and in the mechanism of action of antidepressants has been well appreciated. In humans, brain BDNF levels have been found to be reduced in postmortem samples from depressed patients, and antidepressant therapies restored brain BDNF level to the normal range (Al-Hatamleh et al., 2019). As well as clinical studies, it has also been shown that BDNF expression 
was decreased in the hippocampus and prefrontal cortex of depressive animals, which could be reversed by long term antidepressant treatment (Mendez-David et al., 2015; Sahin et al., 2015). In line with the previous reports, long term red wine extract treatment reversing the reduction of BDNF which suggested that the behavioral improvement in the depressed mice might be related with the regulation of BDNF.

\section{TrkB phosphorylation / TrkB}

As shown in Figure 5, the ratio of pCREB/CREB in the hippocampus $[\mathrm{F}(10,77)=10.291, \mathrm{p}<0.05]$ (Figure $5 \mathrm{~A})$ and prefrontal cortex $[\mathrm{F}(10,77)=9.357, \mathrm{p}<0.05]$ (Figure $5 \mathrm{~B}$ ) of the corticosterone-treated mice were significantly decreased as compared to the control mice.
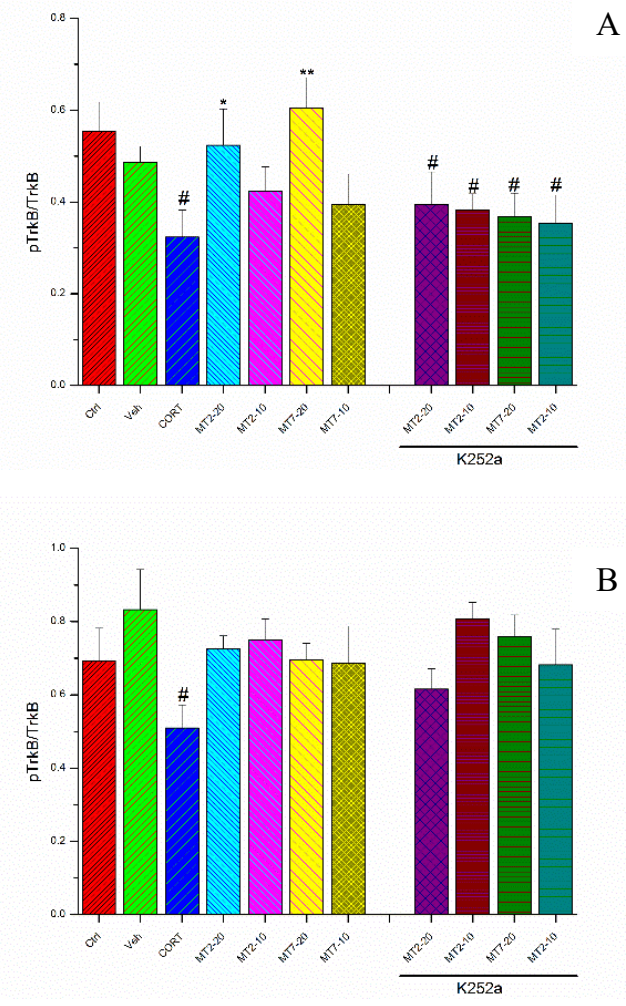

Figure 5. Effect of TPx-MT2 and TPx-MT7 on the ratio of $\mathrm{p}$ TrkB/TrkB of hippocampus (A) and prefrontal cortex (B). All the values are given as mean \pm SEM $(\mathrm{n}=8),{ }^{*} p<0.05,{ }^{* *} p<0.01 v s$ CORT; ${ }^{\#} p<0.05$ vs control

Efeito de TPx-MT2 e TPx-MT7 na relação entre pTrkB / TrkB do hipocampo (A) e córtex pré-frontal (B). Todos os valores são dados como média $\pm \operatorname{SEM}(n=8),{ }^{*} p<0,05,{ }^{* *} p<0,01$ vs CORT; ${ }^{*}<0,05$ vs controlo.

Chronic administration of TPx-MT2 (20 mg/kg) $(\mathrm{p}<0.05) \quad$ and TPx-MT7 $\quad(20 \mathrm{mg} / \mathrm{kg}) \quad(\mathrm{p}<0.01)$ increased the ratio of $\mathrm{pTrkB} / \operatorname{TrkB}$ in the hippocampus. TrkB expressions in the K252ainjected mice were similar to that in corticosteronetreated mice. However, the ratio of $\mathrm{pTrkB} / \mathrm{TrkB}$ in the prefrontal cortex among all other groups was similar to the control group, despite TPx-MT2 or TPx-MT7 administrated or K252a treated. Growing evidence suggests that BDNF-TrkB signaling serves an important role in the regulation of many of the behavioral and molecular mechanisms of antidepressants. BDNF mitigates depressive symptoms mainly by binding to TrkB, leading to the autophosphorylation of $\mathrm{TrkB}$, and the activation of downstream signaling molecules (Mao et al., 2015).To further confirm that the effect of red wine extract was implemented by BDNF signaling, the contribution of BDNF-TrkB signaling to antidepressant-like effect by using a TrkB receptor antagonist K252a was investigated. Previous studies found that blockade of BDNF-TrkB signaling by $\mathrm{K} 252 \mathrm{a}$ abolished the effects of antidepressants in depression-like models (Zhang et al., 2019b). Consistent with previous findings, in the present study, it was found that K252a prevents the behavioral effects of red wine extract on sucrose preference and immobility time in FST. Moreover, the antagonist also inhibited the decrease of serum corticosterone level and the increase of hippocampal and prefrontal cortex BDNF levels and the $\mathrm{pTrkB} /$ TrkB ratio. Considering that there is clear evidence that BDNF signaling through TrkB is involved in the action mechanisms of antidepressants, as mentioned above, the data indicated that the BDNF signaling pathway is necessary for the antidepressantlike effect of red wine extracts.

\section{CREB phosphorylation/ CREB}

As shown in Figure 6, the ratio of pCREB/CREB in the hippocampus $[\mathrm{F}(10,77)=13.527, \mathrm{p}<0.01]$ of corticosterone-treated mice was significantly decreased as compared to the control group. TPXMT2 or TPX-MT7 up-regulated the ratio of pCREB/CREB, and K252a has not abolished it. Similar results were obtained in the prefrontal cortex; all treated groups were not different compared to the control group. CREB is up-regulated by chronic antidepressant treatment, and increasing CREB levels in rodent model results in antidepressant-like behaviors. Furthermore, postmortem studies indicate that CREB levels are increased in subjects taking antidepressants at the time of death (Tian et al., 2019). In agreement with that, the red wine extract treatment significantly increased the ratio of pCREB/CREB in the hippocampus and prefrontal cortex. And K252a did not show any inhibitory effect. 
Thus, the CREB signaling pathway might be involved in the antidepressant-like effect as well.
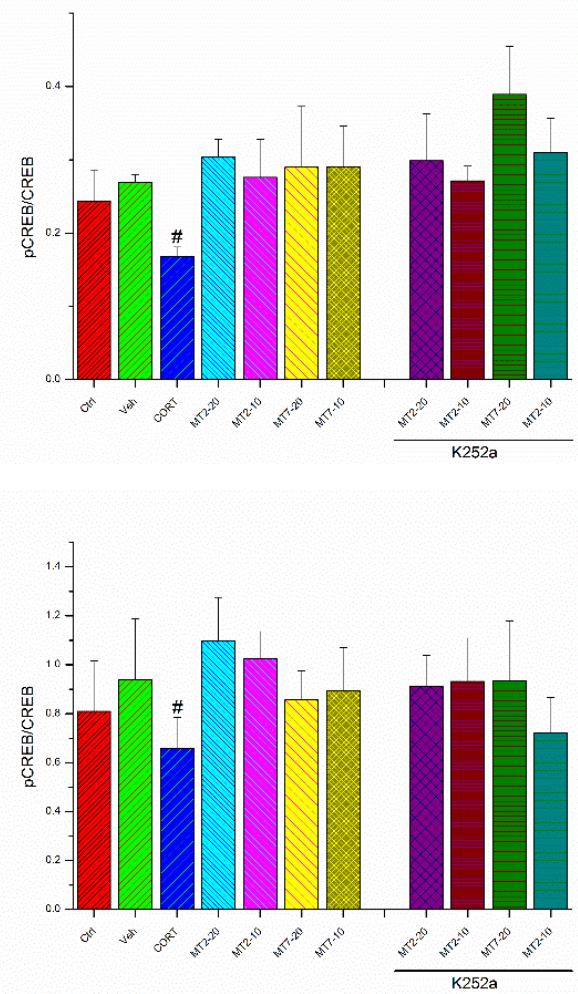

B

Figure 6. Effect of TPx-MT2 and TPx-MT7 on the ratio of pCREB/CREB of hippocampus (A) and prefrontal cortex (B). All the values are given as mean \pm SEM $(\mathrm{n}=8),{ }_{p}^{\#}<0.05$ vs control.

Efeito de TPx-MT2 e TPx-MT7 na relação de pCREB / CREB do hipocampo (A) e córtex pré-frontal (B). Todos os valores são dados como média $\pm \operatorname{SEM}(n=8),{ }^{\#} p<0.05$ vs controlo.

Based on the different preparation procedures, both red wine phenolic extracts present high purity in polyphenols $(>91 \%$; w/w), TPx-MT2 contains more anthocyanins than TPx-MT7 while TPx-MT7 contains more proanthocyanidins than TPx-MT2 (Sun et al., 2011). Comparing the red wine extract treatment groups, it was found that BDNF level and $\mathrm{pTrkB} /$ TrkB ratio in hippocampus of TPx-MT7 is higher than TPx-MT2, especially in TPx-MT7 (20 $\mathrm{mg} / \mathrm{kg}$ ) group. All the above results illustrated that proanthocyanidins are exerting greater antidepressantlike effect than anthocyanins, which is consistent with the data of in vitro antioxidant activities previously published (Sun et al., 2009). However, it was also found that the ratio of pCREB/CREB among TPxMT2 and TPx-MT7 treatment groups both in the hippocampus and prefrontal cortex is similar; this may be caused by the dose or other involved mechanisms and should be investigated in our further studies.

\section{CONCLUSIONS}

Although both red wine phenolic extracts showed their potent reversing the anhedonia effects in the depressed mouse model, TPx-MT7 containing more proanthocyanidins appeared more effective on the antidepressant-like activity than TPx-MT2 containing more anthocyanins, indicating that proanthocyanidins would have a greater antidepressant-like effect than anthocyanins. The antidepressant-like effects may be speculated to be mediated by its modulatory action on the HPA axis function and its ability to prevent the alterations of BDNF, pTrkB/TrkB and pCREB/CREB levels in the hippocampus and prefrontal cortex of depressed mice.

\section{ACKNOWLEDGMENTS}

This research was supported by the National Natural Science Foundation of China (No. 81573580). The authors thank Key Laboratory of polysaccharide bioactivity evaluation of TCM of Liaoning Province, Key techniques study of consistency evaluation of drug quality and therapeutic effect (18-400-4-08), Liaoning Distinguished Professor Project for Ying Jia (2017), and Doctoral Scientific Research Foundation of Liaoning Province (2019-BS-233).

\section{REFERENCES}

Al-Hatamleh M.A.I., Hussin T., Taib W.R.W., Ismail I., 2019. The Brain-Derived Neurotrophic Factor (BDNF) gene Val66Met (rs6265) polymorphism and stress among preclinical medical students in Malaysia. J. Taibah Univ. Med. Sci., 14, 431-438.

Amor S., Chalons P., Aires V., Delmas D., 2018. Polyphenol Extracts from Red Wine and Grapevine: Potential Effects on Cancers. Diseases, 6.

Badescu S.V., Tataru C., Kobylinska L., Georgescu E.L., Zahiu D.M., Zagrean A.M., Zagrean L., 2016. The association between Diabetes mellitus and Depression. J. Med. Life, 9, 120-125.

Buttenschon H.N., Foldager L., Elfving B., Poulsen P.H., Uher R., Mors O., 2015. Neurotrophic factors in depression in response to treatment. J. Affect. Disord., 183, 287-294.

Cerniauskas I., Winterer J., de Jong J.W., Lukacsovich D., Yang H., Khan F., Lammel S., 2019. Chronic stress induces activity, synaptic, and transcriptional remodeling of the lateral habenula associated with deficits in motivated behaviors. Neuron, doi: 10.1016/j.neuron.2019.09.005.

Chiba S., Numakawa T., Ninomiya M., Richards M.C., Wakabayashi C., Kunugi H., 2012. Chronic restraint stress causes anxiety- and depression-like behaviors, downregulates glucocorticoid receptor expression, and attenuates glutamate release induced by brain-derived neurotrophic factor in the prefrontal cortex. Prog. Neuropsychopharmacol. Biol. Psychiatry, 
39, 112-119.

Chong S.A., Vaingankar J., Abdin E., Subramaniam M., 2012. The prevalence and impact of major depressive disorder among Chinese, Malays and Indians in an Asian multi-racial population. $J$. Affect. Disord., 138, 128-136.

Dean J., Keshavan M., 2017. The neurobiology of depression: An integrated view. Asian J. Psychiatr., 27, 101-111.

Ding H., Cui X.Y., Cui S.Y., Ye H., Hu X., Zhao H.L., Zhang Y.H., 2018. Depression-like behaviors induced by chronic corticosterone exposure via drinking water: Time-course analysis. Neurosci. Lett., 687, 202-206.

Fenton E.Y., Fournier N.M., Lussier A.L., Romay-Tallon R., Caruncho H.J., Kalynchuk L.E., 2015. Imipramine protects against the deleterious effects of chronic corticosterone on depression-like behavior, hippocampal reelin expression, and neuronal maturation. Prog. Neuropsychopharmacol. Biol. Psychiatry, 60, 52-59.

Gerritsen L., Milaneschi Y., Vinkers C.H., van Hemert A.M., van Velzen L., Schmaal L., Penninx B.W., 2017. HPA axis genes, and their interaction with childhood maltreatment, are related to cortisol levels and stress-related phenotypes. Neuropsychopharmacology, 42, 2446-2455.

Jani B.D., Boachie C., McCowan C., Barry S.J.E., Cavanagh J., Mair F.S., 2017. Relationship of depression screening in cardiometabolic disease with vascular events and mortality: findings from a large primary care cohort with 4 years follow-up. Eur. Heart J. Qual. Care Clin. Outcomes, 3, 61-73.

Kruk-Slomka M., Michalak A., Biala G., 2015. Antidepressant-like effects of the cannabinoid receptor ligands in the forced swimming test in mice: mechanism of action and possible interactions with cholinergic system. Behav. Brain Res., 284, 24-36.

Leistner C., Menke A., 2018. How to measure glucocorticoid receptor's sensitivity in patients with stress-related psychiatric disorders. Psychoneuroendocrinology, 91, 235-260.

Lima-Ojeda J.M., Rupprecht R., Baghai T.C., 2018. Neurobiology of depression: A neurodevelopmental approach. World J. Biol. Psychiatry, 19, 349-359.

Luo L., Liu X.L., Mu R.H., Wu Y.J., Liu B.B., Geng D., Yi L.T., 2015. Hippocampal BDNF signaling restored with chronic asiaticoside treatment in depression-like mice. Brain Res. Bull., 114, 62-69.

Mao X.Y., Cao Y.G., Ji Z., Zhou H.H., Liu Z.Q., Sun H.L., 2015. Topiramate protects against glutamate excitotoxicity via activating BDNF/TrkB-dependent ERK pathway in rodent hippocampal neurons. Prog. Neuropsychopharmacol. Biol. Psychiatry, 60, 11-17.

Mattera R., Benvenuto M., Giganti M.G., Tresoldi I., Pluchinotta F.R., Bergante S., Bei R., 2017. Effects of polyphenols on oxidative stress-mediated injury in cardiomyocytes. Nutrients, 9.

Mendez-David I., Tritschler L., Ali Z.E., Damiens M.H., Pallardy M., David D.J., Gardier A.M., 2015. Nrf2-signaling and BDNF: A new target for the antidepressant-like activity of chronic fluoxetine treatment in a mouse model of anxiety/depression. Neurosci. Lett., 597, 121-126.

Menke A., 2019. Is the HPA Axis as Target for Depression Outdated, or Is There a New Hope? Front. Psychiatry, 10, 101.

Mulero J., Martinez G., Oliva J., Cermeno S., Cayuela J.M., Zafrilla P., Barba A., 2015. Phenolic compounds and antioxidant activity of red wine made from grapes treated with different fungicides. Food Chem., 180, 25-31.

Nash V., Ranadheera C.S., Georgousopoulou E.N., Mellor D.D., Panagiotakos D.B., McKune A.J., Naumovski N., 2018. The effects of grape and red wine polyphenols on gut microbiota - A systematic review. Food Res. Int., 113, 277-287.

Obasi E.M., Chen T.A., Cavanagh L., Smith B.K., Wilborn K.A., McNeill L.H., Reitzel L.R., 2019. Depression, perceived social control, and hypothalamic-pituitary-adrenal axis function in African-American adults. Health Psychol. doi: $10.1037 /$ hea0000812

Patki G., Ali Q., Pokkunuri I., Asghar M., Salim S., 2015. Grape powder treatment prevents anxiety-like behavior in a rat model of aging. Nutr. Res., 35, 504-511.

Reinhart V., Bove S.E., Volfson D., Lewis D.A., Kleiman R.J., Lanz T.A., 2015. Evaluation of TrkB and BDNF transcripts in prefrontal cortex, hippocampus, and striatum from subjects with schizophrenia, bipolar disorder, and major depressive disorder. Neurobiol. Dis., 77, 220-227.

Rzepa E., McCabe C., 2019. Dimensional anhedonia and the adolescent brain: reward and aversion anticipation, effort and consummation. B. J. Psych. Open, 5, e99.

Sahin T.D., Karson A., Balci F., Yazir Y., Bayramgurler D., Utkan T., 2015. TNF-alpha inhibition prevents cognitive decline and maintains hippocampal BDNF levels in the unpredictable chronic mild stress rat model of depression. Behav. Brain Res., 292, 233240

Solanki N., Alkadhi I., Atrooz F., Patki G., Salim S., 2015. Grape powder prevents cognitive, behavioral, and biochemical impairments in a rat model of posttraumatic stress disorder. Nutr. Res., 35, 65-75.

Sun B., Neves A.C., Fernandes T.A., Fernandes A.L., Mateus N., De Freitas V., Spranger M.I., 2011. Evolution of phenolic composition of red wine during vinification and storage and its contribution to wine sensory properties and antioxidant activity. $J$. Agric. Food Chem., 59, 6550-6557.

Sun B., Spranger I., Yang J., Leandro C., Guo L., Canario S., Wu C., 2009. Red wine phenolic complexes and their in vitro antioxidant activity. J. Agric. Food Chem., 57, 8623-8627.

Tian P., Zou R., Song L., Zhang X., 2019. Ingestion of Bifidobacterium longum subspecies infantis strain CCFM687 regulated emotional behavior and the central BDNF pathway in chronic stress-induced depressive mice through reshaping the gut microbiota. Food Funct., 10, 7588-7598.

Wang C., Guo J., Guo R., 2017. Effect of XingPiJieYu decoction on spatial learning and memory and cAMP-PKA-CREB-BDNF pathway in rat model of depression through chronic unpredictable stress. BMC Complement. Altern. Med., 17, 73.

Yu P., Zhang H., Li X., He F., Tai, F. 2015. Early bi-parental separation or neonatal paternal deprivation in mandarin voles reduces adult offspring paternal behavior and alters serum corticosterone levels and neurochemistry. Horm. Behav., 73, 8-14.

Zhang H., Sun Y., Qian S., Ge R., Guo X., Shen Q., Chen G., 2019a. Yueju-Ganmaidazao Decoction confers rapid antidepressant-like effects and the involvement of suppression of NMDA/NO/cGMP signaling. $J$. Ethnopharmacol., doi: 10.1016/j.jep.2019.112380.

Zhang H., Zhao Y., Wang Z., 2015. Chronic corticosterone exposure reduces hippocampal astrocyte structural plasticity and induces hippocampal atrophy in mice. Neurosci. Lett., 592, 76-81.

Zhang S.S., Tian Y.H., Jin S.J., Wang W.C., Zhao J.X., Si X.M., Jin J.Y., 2019b. Isoflurane produces antidepressant effects inducing BDNF-TrkB signaling in CUMS mice. Psychopharmacology, 236, 3301-3315. 